\title{
ANÁLISE DA DECISÃO JUDICIAL SOBRE A CONSTITUCIONALIDADE DA LEI N. 12.990/2014 (ADC 41) A PARTIR DA TEORIA DA ARGUMENTAÇÃO JURÍDICA DE NEIL MACCORMICK
}

\author{
ANALYSIS OF THE JUDICIAL DECISION ON THE CONSTITUTIONALITY OF LAW NO. \\ 12.990 / 2014 (ADC 41) FROM THE PERSPECTIVE OF NEIL MACCORMICK'S \\ ARGUMENTATION THEORY
}

\section{Eduardo Rocha Dias}

Doutor em Direito pela Universidade de Lisboa (2007). Professor Titular do Programa de Pós-Graduação em Direito da Universidade de Fortaleza. Procurador Federal - categoria especial - da Advocacia-Geral da União.

E-mail: eduardodias@hotmail.com

\section{Marynna Laís Quirino Pereira}

Mestranda em Direito Constitucional Público e Teoria Política pela Universidade de Fortaleza (UNIFOR). Pesquisadora-bolsista da Fundação Cearense de Apoio ao Desenvolvimento Científico e Tecnológico (FUNCAP) (2018-2020).

Graduada em Direito pelo Centro Universitário Christus (UniChristus).

E-mail: marynnalqp@gmail.com

Recebido em: 14/08/2019

Aprovado em: 27/05/2020

RESUMO: Em virtude das últimas tendências do Supremo Tribunal Federal em proferir decisões ativistas, que ultrapassam os limites textuais presentes no ordenamento jurídico, cumpre analisar o teor da decisão acerca da Ação Declaratória de Constitucionalidade (ADC) n. 41. A partir dessa questão, o presente artigo tem como objetivo analisar os votos dos ministros do Supremo Tribunal Federal no julgamento dessa ação à luz da teoria da argumentação jurídica de Neil MacCormick. Para se atingir tal finalidade, inicialmente, será feita uma breve explanação acerca da teoria da argumentação jurídica de Neil MacCormick, focando principalmente nos argumentos interpretativos. Depois, serão analisados os argumentos proferidos pelos ministros em sede da ADC n. 41. Por fim, confrontar-se-á os requisitos de racionalidade argumentativa de Neil MacCormick com a decisão como um todo. Por fim, chega-se à conclusão de que a decisão como um todo preenche os requisitos de racionalidade apresentados, contudo, ao analisar alguns votos específicos isso não ocorre.

Palavras-chave: ADC 41; Argumentação Jurídica; Neil MacCormick; Supremo Tribunal Federal.

ABSTRACT: Due to the latest tendencies of the Federal Supreme Court in rendering activist decisions, which are beyond the textual provisions of the Brazilian legal system, it is necessary to analyze the content of the decision issued in the Declaratory Action of Constitutionality n. 41. From this point of view, this article aims to analyze the opinions of the Federal Supreme Court justices 
in light of Neil MacCormick's theory of legal argumentation. In order to achieve such a purpose, a brief explanation of Neil MacCormick's theory of legal argumentation will be made, focusing primarily on interpretive arguments. Then, the arguments given by the justices in ADC n. 41 . Finally, it will confront Neil MacCormick's requirements for argumentative rationality with the decision as a whole. Finally, the research comes to the conclusion that the decision as a whole fulfills the presented rationality requirements, however, when analyzing some specific opinions this does not happen.

Keywords: ADC 41; Legal Argumentation; Neil MacCormick; Federal Supreme Court.

SUMÁRIO: Introdução. 1 Uma breve explanação acerca da Teoria da Argumentação Jurídica de Neil Maccormick. 2 Análise dos argumentos interpretativos invocados na decisão acerca da ADC 41. 3 Avaliação do acordão conforme os requisitos de universalidade, consistência, coerência e consequência propostos por Neil Maccormick. 3.1 Universalidade. 3.2 Consistência. 3.3 Coerência. 3.4 Consequência. Conclusão. Referências.

\section{INTRODUÇÃO}

Nos últimos tempos, percebe-se uma tendência legislativa a criar dispositivos normativos de promoção da igualdade material por meio de ações afirmativas. Amparam-se tais dispositivos na visão de que a igualdade pode ser alcançada não apenas de forma negativa, pelo afastamento de medidas discriminatórias, mas também de forma positiva, pela introdução de mecanismos de desigualação e de atribuição de vantagens a determinados grupos tradicionalmente situados em posição de desvantagem. Alguns dessas medidas se encaminham no sentido de conferir reserva de vagas para negros em processos seletivos. Inicialmente, tal iniciativa se deu na Universidade de Brasília, que estabeleceu o percentual de $20 \%$ das vagas do vestibular para candidatos negros.

Essa questão ensejou a Ação de Descumprimento de Preceito Fundamental (ADPF) n. 186, que foi analisada pelo Supremo Tribunal Federal, o qual decidiu, no dia 31 de julho de 2009, pela improcedência do pedido, ao afirmar que não havia qualquer afronta ao princípio da igualdade. O teor dessa decisão se tornou paradigmático, sendo necessário que os demais julgamentos do tribunal o observem. Ou seja, um julgamento que foi a favor da promoção da igualdade material e da compensação histórica pelo tratamento conferido aos negros no Brasil.

A referida providência da Universidade de Brasília foi seguida pela edição da Lei de n. 12.711 de 29 de agosto de 2012, referente ao acesso ao ensino superior. Dois anos depois, foi publicada a Lei n. 12.990 de 9 de junho de 2014, que reserva aos negros $20 \%$ (vinte por cento) das vagas oferecidas nos concursos públicos para provimento de cargos efetivos e empregos públicos no âmbito da administração pública federal, das autarquias, das fundações públicas, das empresas públicas e das sociedades de economia mista controladas pela União.

Nesse sentido, o presente artigo tem como objetivo analisar os votos dos ministros do Supremo Tribunal Federal em sede da Ação Declaratória de Constitucionalidade (ADC) n. 41, que versa sobre a Lei de n. 12.990/2014. O exame da decisão se dá com base na teoria da argumentação jurídica de Neil MacCormick, que propõe parâmetros para identificar se os julgamentos foram fundamentados corretamente, apresentando argumentos racionais.

Assim, para a construção do presente artigo, a abordagem é qualitativa, haja vista que se deseja analisar o conteúdo dos votos dos ministros, sem fazer qualquer avaliação quantificável. Quanto a natureza, é do tipo básica, pois não se pretende propor uma nova solução, apenas explorar as bases teóricas e explicar o porquê da decisão se mostrar irracional ou racional, nesse sentido, é uma pesquisa exploratória e explicativa. Quanto ao método é do tipo hipotético-dedutivo, visto que se busca testar a hipótese de que o Supremo Tribunal Federal, em matéria da ADC n. 41, proferiu 
uma correta decisão, ao mesmo tempo que se fará isso partindo do todo para o específico. Os dados serão coletados por meio de pesquisa bibliográfica e documental.

Para tanto, o trabalho está estruturado de modo que, inicialmente, será feita uma breve explanação acerca da teoria da argumentação de Neil MacCormick, com foco, principalmente, nos argumentos interpretativos por ele elencados. Depois, os votos proferidos por cada um dos ministros serão confrontados com tais argumentos, de forma a verificar a existência de razões de tipo linguísticas, sistêmicas, teleológicas e deontológicas. Por fim, far-se-á uma breve explicação acerca dos requisitos de racionalidade propostos por MacCormick, para então, relacioná-los com a ADC 41, de modo a compreender se a decisão nela proferida se mostra correta e racional.

\section{UMA BREVE EXPLANAÇÃO ACERCA DA TEORIA DA ARGUMENTAÇÃO JURÍDICA DE NEIL MACCORMICK}

Com o fim da $2^{\mathrm{a}}$ Grande Guerra e as reflexões acerca das marcas por ela deixada, a humanidade passou a questionar as diversas instituições existentes, de modo a buscar meios pelos quais as atrocidades ocorridas naquele tempo não viessem a se repetir. Nesse sentido, a própria ciência do Direito passou a reavaliar as suas bases e a questionar até que ponto o positivismo pode ter contribuído para legitimar o pensamento nazista.

A teoria pura do direito de Hans Kelsen, na qual Direito e Moral deveriam estar dissociados, já não era mais cabível. Contudo, ao mesmo tempo, o retorno do jusnaturalismo, baseado em conceitos vagos, metafísicos e abstratos não era desejado. Desse modo, surge o póspositivismo com o objetivo de superar o conhecimento anterior, reincorporando os conceitos de justiça e legitimidade ao Direito. ${ }^{1}$

Assim, os princípios, que desde longa data desempenham diferentes papéis no mundo jurídico, passaram a ser reconhecidos por meio da normatividade e a abrigarem os valores da sociedade. Concomitantemente, eles sobrevieram como guias ao intérprete, condicionando as suas atividades. Tal força se deu em parte graças a Teoria dos Direitos Fundamentais de Robert Alexy, na qual os princípios obtiveram o status de norma jurídica, principalmente, no Brasil.

Dessarte, a valorização dos princípios, em conjunto com a necessidade da atuação do intérprete, ocasionou ao Poder Judiciário uma posição de maior protagonismo no âmbito das relações jurídicas. Entretanto, de acordo com Lênio Luiz Streck ${ }^{2}$ tal atuação vem sendo confundida como a possibilidade de justificar decisões "sem qualquer critério de racionalidade, baseadas na mais pura discricionariedade".

Desse modo, Neil MacCormick ${ }^{3}$ propõe um processo de avaliação da racionalidade das decisões proferidas por magistrados, ou seja, o processo de tomada de decisões e a sua justificativa no direito. Tal teoria funciona como parâmetro para identificar até que ponto as sentenças judiciais estão dentro dos preceitos normativos ou jazem de caráter discricionário.

Nesse sentido, a teoria de Neil MacCormick busca harmonizar a razão prática de Kant com o ceticismo humano. Sendo assim, uma teoria que se situa entre o ultrarracionalismo de Dworkin, e a tese da resposta única; e a irracionalidade de Alf Ross, em que as decisões jurídicas são essencialmente arbitrárias. ${ }^{4}$ Considerando-se que, o que faz o ser humano aderir a determinados princípios, e não outros, são critérios de caráter racional e irracional.

\footnotetext{
${ }^{1}$ BARROSO, Luís Roberto. Fundamentos teóricos e filosóficos do novo Direito Constitucional brasileiro. Revista de Direito Administrativo, v. 225, p. 5 - 37, jul.set. 2001.

${ }^{2}$ STRECK, Lenio Luiz. Entre o ativismo e a judicialização da política: a difícil concretização do direito fundamental a uma decisão judicial constitucionalmente adequada. Espaço Jurídico Journal of Law [EJJL], v. 17, n. 3, p. 721732, 2016, p. 721.

${ }^{3}$ MACCORMICK, Neil. Argumentação jurídica e teoria do direito. 2. ed. São Paulo: WMF Martins Fontes, 2009.

4 ATIENZA, Manuel. As razões do direito: teoria da argumentação jurídica. 2. ed. Rio de Janeiro: Forense Universitária, 2014.
} 
Apresenta-se, portanto, um processo de argumentação como método justificador das decisões judiciais, de modo a avaliar o grau de racionalidade e de discricionariedade. Assim, para Neil MacCormick "somente aqueles argumentos que demonstram por que motivo se deveria fazer $x$ são razões para exigir que se faça $x$, ou para fazê-lo". Haja vista que, apenas deter o argumento de autoridade não é suficiente para justificar a decisão, sendo necessário, para tanto, fundamentos capazes de convencer que a opção escolhida é a mais adequada ao caso, por meio da racionalidade, a autoridade do argumento.

A função justificadora busca oferecer razões que mostrem que a decisão em questão garante a justiça de acordo com o Direito. Contudo, antes de ser justo, o Direito deve ser lógico, no sentido técnico, os argumentos devem apresentar coerência. Isso posto, a finalidade da teoria é averiguar "a adequação do raciocínio que as justificam". 6

Dessa forma, Neil MacCormick ${ }^{7}$ aponta que a interpretação é uma forma de argumentação prática no Direito, na qual se busca compreender a legislação como uma classe especial de justificativa das decisões judiciais, podendo ser elucidada em um panorama mais amplo da normatividade constitucional. Contudo, não podem ser "as únicas razões nas quais as decisões judiciais podem se pautar". 8

Logo, a interpretação é consequência inevitável, de modo que qualquer aplicação de lei requer anteriormente $o$ ato de interpretação. Nesse sentido, Neil MacCormick ${ }^{9}$ classifica os argumentos interpretativos em três categorias, quais são argumentos do tipo: linguísticos, sistêmicos e teleológicos-deontológicos.

Os argumentos linguísticos podem ser divididos em significado técnico ou comum. Esses são compreendidos por meio do emprego do senso habitual, em que tanto na linguagem comum quanto na jurídica possuem a mesma acepção. Enquanto aqueles são entendidos por meio do vocabulário especializado, dentro de um contexto jurídico. ${ }^{10}$

Martonio Mon'Alverne Barreto Lima e Rafael Gonçalves Mota ${ }^{11}$ exemplificam tal questão por meio do vocábulo "casa”, em que, no Direito, pode-se utilizar dessa acepção no sentido ordinário, mas, ao mesmo tempo, há o emprego de conceito próprio e abrangente. Nesse sentido, quando o legislador define um conceito, o intérprete deve aplicá-lo, não podendo ignorá-lo no todo ou em parte e nem modificar o significado original.

Os argumentos sistêmicos são um conjunto de argumentos que trabalham para o entendimento aceitável do texto legal visto como parte do ordenamento jurídico. ${ }^{12}$ Dessa forma,

\footnotetext{
${ }^{5}$ MACCORMICK, Neil. Argumentação jurídica e teoria do direito. 2. ed. São Paulo: WMF Martins Fontes, 2009, p. 19.

${ }^{6}$ LOPES, Ana Maria D.; BENÍCIO, Márcio. Análise da decisão judicial sobre a "briga de galos"(ADIN nº 1.856/2011) a partir da teoria argumentativa de Neil Maccormick. Revista Brasileira de Direito Animal, Salvador, v. 10, n. 20, p. 37-58, 2015, p. 41.

${ }^{7}$ MACCORMICK, Neil. Argumentación e interpretación en el Derecho. Doxa, Cuadernos de Filosofía del Derecho, v. 33, p. 55-78, 2010.

${ }^{8}$ LOPES, Ana Maria D.; BENÍCIO, Márcio. Análise da decisão judicial sobre a "briga de galos"(ADIN nº 1.856/2011) a partir da teoria argumentativa de Neil Maccormick. Revista Brasileira de Direito Animal, Salvador, v. 10, n. 20, p. 37-58, 2015, p. 41.

${ }^{9}$ MACCORMICK, Neil. Argumentación e interpretación en el Derecho. Doxa, Cuadernos de Filosofía del Derecho, v. 33, p. 55-78, 2010.

${ }^{10}$ LOPES, Ana Maria D.; BENÍCIO, Márcio. Análise da decisão judicial sobre a "briga de galos"(ADIN nº 1.856/2011) a partir da teoria argumentativa de Neil Maccormick. Revista Brasileira de Direito Animal, Salvador, v. 10, n. 20, p. 37-58, 2015.

${ }^{11}$ LIMA, Martonio Mont'Alverne Barreto; MOTA, Rafael Gonçalves. O julgamento do Habeas Corpus 126.292/SP pelo supremo tribunal federal sob a óptica do pensamento de Neil Maccormick sobre argumentação da decisão judicial. Revista Observatório, v. 4, n. 5, p. 750-787, 2018.

${ }^{12}$ MACCORMICK, Neil. Argumentación e interpretación en el Derecho. Doxa, Cuadernos de Filosofía del Derecho, v. 33, p. 55-78, 2010.
}

Revista de Direito Brasileira | Florianólopis, SC | v. 25 | n. 10 | p. 35-55 | Jan./Abr. 2020 
para Martonio Mon'Alverne Barreto Lima e Rafael Gonçalves Mota ${ }^{13}$, a interpretação deve "considerar o dispositivo normativo dentro do contexto em que foi criado", assim como, "o texto legal e constitucional em que foi criado, estruturado e desenvolvido". Objetivando, assim, "encontrar o melhor sentido da norma em relação ao sistema jurídico em todo o seu contexto". ${ }^{14}$

Para tanto, faz-se preciso avaliar a norma por diferentes perspectivas. Nesse diapasão, como as razões sistêmicas são um conjunto de argumentos, então eles englobam outros tipos de fundamentos, classificados por Neil MacCormick ${ }^{15}$ em seis tipos. Sendo eles argumentos: de harmonização contextual, de precedente, de analogia, lógico-conceitual, princípios-gerais do Direito e de história.

A harmonização contextual se refere à necessidade de a interpretação ser conforme o conjunto ou a disposição de lei que tem relação mais próxima. Assim, "a interpretação de determinado dispositivo legal deve ser feita tomando como base não apenas o sistema jurídico em que está inserida, mas especialmente os termos na norma constitucional que a fundamenta". ${ }^{16}$

Para Neil MacCormick ${ }^{17}$, o argumento de precedente se relaciona com a necessidade de interpretar o caso ou a norma em conformidade com a interpretação que já foi dada por outros tribunais. Nesse sentido, decisões anteriores devem servir de paradigmas para novos casos, visando garantir a segurança jurídica e a manutenção da coerência.

A razão analógica busca estabelecer sentidos semelhantes para dispositivos legais equivalentes. Ou seja, se a norma a ser aplicada for parecida com outra regra, então pode ser interpretada adequada em conformidade com essa. ${ }^{18}$

Conforme Neil MacCormick ${ }^{19}$, o argumento lógico-conceitual é firmado na proposição de que se a acepção é conhecida e reproduzida na formulação de alguma norma, então ela deve ser interpretada de tal forma. Podendo, assim, ser aplicada no sistema jurídico como um todo.

Ao passo que o argumento dos princípios gerais do Direito deve ser feito de modo que a interpretação se relacione com o princípio que está sendo aplicado ao caso. "Com isso a interpretação a ser dada a uma norma ou enunciado legal é aquela que esteja em harmonia com o princípio geral de direito que fundamenta e dá suporte, ou ainda, que esteja de alguma forma ligada". ${ }^{20}$

Por fim, Neil MacCormick ${ }^{21}$ estabelece que a lei deve ser interpretada de tal forma que sua aplicação a casos específicos seja compatível com a compreensão historicamente desenvolvida.

\footnotetext{
${ }^{13}$ LIMA, Martonio Mont'Alverne Barreto; MOTA, Rafael Gonçalves. O julgamento do Habeas Corpus 126.292/SP pelo supremo tribunal federal sob a óptica do pensamento de Neil Maccormick sobre argumentação da decisão judicial. Revista Observatório, v. 4, n. 5, p. 750-787, 2018, p. 1713.

${ }^{14}$ LOPES, Ana Maria D.; BENÍCIO, Márcio. Análise da decisão judicial sobre a "briga de galos"(ADIN n 1.856/2011) a partir da teoria argumentativa de Neil Maccormick. Revista Brasileira de Direito Animal, Salvador, v. 10, n. 20, p. 37-58, 2015, p. 42.

${ }^{15}$ MACCORMICK, Neil. Argumentación e interpretación en el Derecho. Doxa, Cuadernos de Filosofía del Derecho, v. 33, p. 55-78, 2010.

${ }^{16}$ LIMA, Martonio Mont'Alverne Barreto; MOTA, Rafael Gonçalves. O julgamento do Habeas Corpus 126.292/SP pelo supremo tribunal federal sob a óptica do pensamento de Neil Maccormick sobre argumentação da decisão judicial. Revista Observatório, v. 4, n. 5, p. 750-787, 2018, p. 1713.

${ }^{17}$ MACCORMICK, Neil. Argumentación e interpretación en el Derecho. Doxa, Cuadernos de Filosofía del Derecho, v. 33, p. 55-78, 2010.

${ }^{18}$ LOPES, Ana Maria D.; BENÍCIO, Márcio. Análise da decisão judicial sobre a "briga de galos"(ADIN n 1.856/2011) a partir da teoria argumentativa de Neil Maccormick. Revista Brasileira de Direito Animal, Salvador, v. 10, n. 20, p. 37-58, 2015.

${ }^{19}$ MACCORMICK, Neil. Argumentación e interpretación en el Derecho. Doxa, Cuadernos de Filosofía del Derecho, v. 33, p. 55-78, 2010.

${ }^{20}$ LIMA, Martonio Mont'Alverne Barreto; MOTA, Rafael Gonçalves. O julgamento do Habeas Corpus 126.292/SP pelo supremo tribunal federal sob a óptica do pensamento de Neil Maccormick sobre argumentação da decisão judicial. Revista Observatório, v. 4, n. 5, p. 750-787, 2018, p. 1714.

${ }^{21}$ MACCORMICK, Neil. Argumentación e interpretación en el Derecho. Doxa, Cuadernos de Filosofía del Derecho, v. 33, p. 55-78, 2010.
}

Revista de Direito Brasileira | Florianólopis, SC | v. 25 | n. 10 | p. 35-55 | Jan./Abr. 2020 
Nesse ínterim, "se um dispositivo tem sido interpretado durante um tempo de acordo com o objetivo ou finalidade histórica, esse sentido deve ser preferido na aplicação de casos específicos". ${ }^{22}$

Finalizando, assim, as espécies de argumentos sistêmicos, passa-se a explicar os argumentos de caráter teleológico-deontológico. Para Neil MacCormick ${ }^{23}$, argumentos teleológicos buscam a razão para decidir de um modo ou de outro, mas tomando como base as consequências que a decisão irá ocasionar. Assim, refere-se à finalidade da legislação.

Enquanto que, os argumentos deontológicos buscam identificar o que é correto ou não, utiliza-se de princípios sobre o que se deve decidir. Sendo considerados meios de justiça. Desse modo, o intérprete deve buscar compreender "qual era o objetivo principal [do legislador] ao definir o enunciado normativo, especialmente considerando aqueles que são mais justos ou corretos para com isso obter-se decisão ainda mais válidas e legítimas". ${ }^{24}$

Contudo, em alguns casos, o uso combinado dessas três categorias de interpretação pode gerar conflitos. Haja vista que, argumentos de diferentes tipos dentro da mesma categoria não vão obrigatoriamente seguir a mesma direção, havendo a possibilidade de conflitos entre argumentos da mesma categoria ou entre classificações diferentes. Para tanto, deve existir uma etapa da argumentação que se ocupe da hierarquia dos argumentos quando entrarem em conflito.

Assim, Neil MacCormick ${ }^{25}$ propõe a "regra de ouro" como possível elemento solucionador da problemática. Deve-se dar início pelos argumentos linguísticos, logo depois passar para os sistêmicos, e recorrer ao teleológico/deontológico quando os argumentos das outras classes não solucionarem o conflito. Dessa forma, "os argumentos linguísticos, são prioritários e suficientes quando não negados pelos sistêmicos, de modo que os argumentos teleológicosdeontológicos seriam desprezados nesses casos". ${ }^{26}$

Contudo, em casos difíceis não se pode limitar a interpretação a utilização de argumentos linguísticos, havendo a necessidade de recorrer aos demais tipos, a fim de verificar a correta racionalidade da decisão em questão. Nesse sentido, no tópico a seguir, far-se-á a análise dos votos dos ministros do Supremo Tribunal Federal, tomando como base as categorias argumentativas explanadas nesse tópico.

\section{ANÁLISE DOS ARGUMENTOS INTERPRETATIVOS INVOCADOS NA DECISÃO ACERCA DA ADC 41}

O acórdão a ser analisado no presente artigo se refere à ADC n. 41, que tem como objetivo sanar as controvérsias jurídicas sobre a constitucionalidade da Lei de n. 12.990, de 9 de junho de 2014. Tal legislação se refere à reserva aos candidatos negros de $20 \%$ (vinte por cento) das vagas oferecidas nos concursos públicos para provimento de cargos efetivos e empregos públicos no âmbito da administração pública federal direta e indireta.

\footnotetext{
${ }^{22}$ LOPES, Ana Maria D.; BENÍCIO, Márcio. Análise da decisão judicial sobre a "briga de galos"(ADIN nº 1.856/2011) a partir da teoria argumentativa de Neil Maccormick. Revista Brasileira de Direito Animal, Salvador, v. 10, n. 20, p. 37-58, 2015, p. 43.

${ }^{23}$ MACCORMICK, Neil. Argumentación e interpretación en el Derecho. Doxa, Cuadernos de Filosofía del Derecho, v. 33, p. 55-78, 2010.

${ }^{24}$ LIMA, Martonio Mont'Alverne Barreto; MOTA, Rafael Gonçalves. O julgamento do Habeas Corpus 126.292/SP pelo supremo tribunal federal sob a óptica do pensamento de Neil Maccormick sobre argumentação da decisão judicial. Revista Observatório, v. 4, n. 5, p. 750-787, 2018, p. 1715.

${ }^{25}$ MACCORMICK, Neil. Argumentación e interpretación en el Derecho. Doxa, Cuadernos de Filosofía del Derecho, v. 33, p. 55-78, 2010, p. 75.

${ }^{26}$ LOPES, Ana Maria D.; BENÍCIO, Márcio. Análise da decisão judicial sobre a "briga de galos"(ADIN nº 1.856/2011) a partir da teoria argumentativa de Neil Maccormick. Revista Brasileira de Direito Animal, Salvador, v. 10, n. 20, p. 37-58, 2015, p. 43.
}

Revista de Direito Brasileira | Florianólopis, SC | v. 25 | n. 10 | p. 35-55 | Jan./Abr. 2020 
A ação foi proposta pelo Conselho Federal da Ordem dos Advogados do Brasil (CFOAB), haja vista que alguns juízos estavam declarando a inconstitucionalidade da reserva de vagas, bem como, do sistema de autodeclaração. A continuidade de tal questão, sem qualquer decisão da corte suprema poderia ensejar a ausência de estabilidade e previsibilidade na aplicação da ação afirmativa.

Assim, os Ministros do Supremo Tribunal Federal decidiram, em duas sessões, uma realizada no dia 11 de maio de 2017 e outra no dia 08 de junho de 2017, por unanimidade e nos termos do voto do relator, Ministro Luís Roberto Barroso, pela procedência da ação, declarando que a Lei n. 12.990/2014 é constitucional.

De modo que está em consonância com o princípio da isonomia, ao mesmo tempo em que, não há violação aos princípios do concurso público e da eficiência. Além da medida observar o princípio da proporcionalidade em sua tríplice dimensão. Destacando que é cabível a utilização da autodeclaração e da heteroidentificação, como critério subsidiário, para evitar fraudes e garantir a efetividade da política. ${ }^{27}$

Nesse sentido, no presente tópico serão expostos os principais argumentos de cada ministro, que proferiram votos no teor da ADC n. 41, os quais serão expostos sinteticamente por meio de tabelas. Não serão realizadas as indicações dos argumentos trazidos pelo CFOAB e pela ementa do julgamento, haja vista a procedência do pedido e a unanimidade dos votos.

Cumpre mencionar que no acórdão foi explicitado que apenas o Ministro Gilmar Mendes estava ausente no momento do julgamento, por isso, deixando de proferir um voto. Desse modo, estavam presentes dez ministros. Contudo, não há voto expresso do Ministro Marco Aurélio, apenas uma pequena menção acerca de sua total concordância com o relator. ${ }^{28}$

Assim, passa-se a destacar os principais argumentos acolhidos por cada ministro e sua correta divisão, conforme os argumentos interpretativos linguísticos, sistêmicos, teleológicos e deontológicos observados.

\section{Quadro 1 - Argumentos de Interpretação identificados no voto do Ministro Luís Roberto} Barroso

\begin{tabular}{|c|c|}
\hline Páginas do Acórdão & 28 a 66 \\
\hline $\begin{array}{l}\text { Argumentos } \\
\text { Linguísticos }\end{array}$ & $\begin{array}{l}\text { a. As ações afirmativas em geral e a reserva de vagas para ingresso no serviço } \\
\text { público em particular são políticas públicas voltadas para a efetivação do } \\
\text { direito à igualdade; } \\
\text { b. a Constituição de } 1988 \text { contempla essas três dimensões da igualdade. A } \\
\text { igualdade formal vem prevista no art. } 5^{\circ} \text {, caput: "todos são iguais perante a } \\
\text { lei, sem distinção de qualquer natureza". Já a igualdade como redistribuição } \\
\text { decorre de objetivos da República, como "construir uma sociedade livre, justa } \\
\text { e solidária" (art. 3o, I) e "erradicar a pobreza e a marginalização e reduzir as } \\
\text { desigualdades sociais e regionais" (art. 3o, III). Por fim, a igualdade como } \\
\text { reconhecimento tem lastro nos objetivos fundamentais do país de "promover } \\
\text { o bem de todos, sem preconceitos de origem, raça, sexo, cor, idade e } \\
\text { quaisquer outras formas de discriminação" (art. 3o, IV), bem como no repúdio } \\
\text { ao racismo (art. 5o. XLII); } \\
\text { fundada na necessidade de superar o racismo estrutural, a política instituída } \\
\text { pela Lei n' } 12.990 / 2014 \text { tem como um de seus objetivos promover uma }\end{array}$ \\
\hline
\end{tabular}

\footnotetext{
${ }^{27}$ Em 6 de abril de 2018, o Ministério do Planejamento, Desenvolvimento e Gestão emitiu a portaria de n. 4, que tem como objetivo regulamentar o procedimento de heteroidentificação complementar à autodeclaração dos candidatos negros, no que se refere ao preenchimento da reserva de vagas nos concursos públicos federais, conforme a Lei $\mathrm{n}$. 12.990 de 2014, com o intuito de controle e combate a fraudes.

${ }^{28}$ BRASIL. Supremo Tribunal Federal. Ação Declaratória de Constitucionalidade $n^{\circ} 41$. Requerente: Conselho Federal da Ordem dos Advogados do Brasil - CFOAB. Relator: Ministro Luís Roberto Barroso. Brasília, DF, 08 de junho de 2017. Diário Oficial da União: Constitucionalidade da Lei m. 12.990/2014. Brasília, 16 ago. 2017. p. 1-186. Disponível em: <http://portal.stf.jus.br/processos/downloadPeca.asp?id=312447860\&ext=.pdf〉. Acesso em: 15 out. 2018, p. 137.
} 
redistribuição de riquezas e de poder na sociedade, por meio da expansão do acesso de negros ao serviço público federal;

d. a seleção dos candidatos com a melhor colocação (em termos objetivos) nos concursos públicos seria uma exigência do princípio da eficiência;

e. a Constituição Federal de 1988 instituiu, como regra, a exigência da realização de concurso público de provas ou provas e títulos para a investidura em cargo no âmbito da Administração Pública (art. 37, II);

f. esses princípios vedam, portanto, são as desequiparações arbitrárias e injustificadas, que não tenham um fundamento racional e razoável e que não se destinem a promover um fim constitucionalmente legítimo.

a. O Supremo Tribunal Federal já se manifestou sobre diversas questões que estão também em discussão nesta ADC, de modo a possibilitar a aplicação de muitas das suas conclusões à presente ação, com as devidas adaptações. Esse é o caso, por exemplo, da própria constitucionalidade de políticas de ação afirmativa voltadas para o enfrentamento de desigualdades materiais entre brancos e afrodescendentes;

b. a sociedade brasileira é profundamente desigual e que, por isso, não se poderia aferir o mérito dos candidatos a partir de critério puramente linear;

c. a universalização prevista e pretendida pela Constituição é apenas a dos ensinos fundamental (educação básica) e médio (CF/1988, art. 208, I e II);

d. a igualdade veda a hierarquização dos indivíduos e as desequiparações infundadas, mas impõe a neutralização das injustiças históricas, econômicas e sociais, bem como o respeito à diferença;

e. a ordem constitucional não apenas rejeita todas as formas de preconceito e discriminação, mas também impõe ao Estado o dever de atuar positivamente no combate a esse tipo de desvio e na redução das desigualdades de fato;

f. a própria Constituição admite o emprego de políticas de ações afirmativas, ao instituí-las diretamente em relação às pessoas portadoras de deficiência, determinando que a lei deverá reservar a elas percentual dos cargos e empregos públicos (CF/1988, art. 37, VIII);

g. além de já reconhecida pela ONU, a existência de um racismo estrutural e institucional no Brasil é facilmente revelada por análises estatísticas;

h. a eloquência dos números demonstra que a ideia de democracia racial representa uma máscara que tem dificultado tremendamente o enfrentamento dos processos históricos e culturais de discriminação contra a população afrodescendente;

Sistêmicos

i. a reserva de vagas para negros no serviço público se volta a combater o racismo estrutural presente na sociedade brasileira, na linha dos compromissos firmados pela Constituição de 1988 com a promoção da igualdade em seu sentido material, com a redução das desigualdades e com o combate ao racismo (CF/1988, arts. $3^{\circ}$, III e $5^{\circ}$, caput e XLII);

j. a reserva de vagas para negros em concursos públicos instituída pela Lei $\mathrm{n}^{\circ}$ $12.990 / 2014,[\ldots]$ mais do que compatível com a Constituição, realiza adequadamente os fins por ela propugnados, no sentido de efetivar a igualdade material;

k. o concurso permite que o acesso ao serviço público se dê mediante um regime de livre concorrência, com igualdade de oportunidade de acesso para todos os candidatos e impessoalidade nos critérios de seleção. Trata-se, sob essa perspectiva, de uma aplicação dos princípios da isonomia, da impessoalidade e da moralidade administrativa;

1. a condução do concurso público de forma isonômica e impessoal materializa a ideia típica dos Estados democráticos a respeito do igual valor de todos perante a lei e, consequentemente, perante a Administração;

m. o princípio da eficiência relaciona-se com as ideias de custo/benefício, economicidade administrativa e sucesso na realização da finalidade pública de modo a que se produza o atendimento satisfatório das necessidades da comunidade e de seus membros, particularmente no que toca aos serviços públicos;

n. a administração já adota, para fins de definir a ordem de classificação no concurso, outros parâmetros alheios ao "mérito", como a reserva de vagas 


\begin{tabular}{|c|c|c|}
\hline & & $\begin{array}{l}\text { para pessoas portadoras de deficiência (CF/1988, art. 37, VIII) e o emprego } \\
\text { da idade dos candidatos como critério de desempate (Lei } \mathrm{n}^{\circ} 10.741 / 2003 \text {, } \\
\text { Estatuto do Idoso). }\end{array}$ \\
\hline $\begin{array}{l}\text { Argumentos } \\
\text { Teleológicos }\end{array}$ & & $\begin{array}{l}\text { Os empregos conquistados por meio desta política de ação afirmativa } \\
\text { garantem um maior nível de renda às famílias de seus beneficiários e } \\
\text { permitem que seus filhos iniciem a vida em igualdade de condições; } \\
\text { a reserva de vagas para negros em concursos públicos atua no sentido de } \\
\text { promover a superação dos estereótipos, a valorização da diferença e o } \\
\text { pluralismo, em linha com os objetivos constitucionais de alcançar a igualdade } \\
\text { material, não somente no campo da distribuição de bens sociais, mas também } \\
\text { no campo do reconhecimento; } \\
\text { incorporação do fator "raça" como critério de seleção, ao invés de afetar o } \\
\text { princípio da eficiência, permite sua realização em maior extensão, na medida } \\
\text { em que pode contribuir para que todos os pontos de vista e interesses da } \\
\text { comunidade e de seus membros sejam considerados na tomada de decisões } \\
\text { estatais. }\end{array}$ \\
\hline $\begin{array}{c}\text { Argumentos } \\
\text { Deontológicos }\end{array}$ & & $\begin{array}{l}\text { A reserva de vagas instituída pela Lei } \mathrm{n}^{\circ} 12.990 / 2014 \text { constitui política } \\
\text { corretiva da desigualdade material existente entre brancos e negros na } \\
\text { disputa, no âmbito de concursos públicos, pela assunção de cargos efetivos e } \\
\text { empregos públicos na administração pública federal. }\end{array}$ \\
\hline
\end{tabular}

Fonte: Elaborado pelos autores.

\section{Quadro 2 - Argumentos de Interpretação identificados no voto do Ministro Alexandre de Moraes}

\begin{tabular}{|c|c|}
\hline Páginas do Acórdão & 70 a 86 \\
\hline $\begin{array}{l}\text { Argumentos } \\
\text { Linguísticos }\end{array}$ & $\begin{array}{l}\text { a. A Constituição Federal de } 1988 \text { adotou o princípio da igualdade de direitos, } \\
\text { prevendo a igualdade de aptidão, uma igualdade de possibilidades virtuais, } \\
\text { ou seja, todos os cidadãos têm o direito de tratamento idêntico pela lei, em } \\
\text { consonância com os critérios albergados pelo ordenamento jurídico; } \\
\text { b. o princípio da igualdade, portanto, sustenta a constitucionalidade do recorte } \\
\text { racial para a reserva de vagas nos concursos públicos em postos da } \\
\text { Administração Pública e, logicamente, deve ser aplicado como um dos } \\
\text { princípios básicos da administração pública, previsto no artigo } 37 \text { da } \\
\text { Constituição Federal. }\end{array}$ \\
\hline $\begin{array}{l}\text { Argumentos } \\
\text { Sistêmicos }\end{array}$ & $\begin{array}{l}\text { a. Os tratamentos normativos diferenciados são compatíveis com a Constituição } \\
\text { Federal quando verificada a existência de uma finalidade razoavelmente } \\
\text { proporcional ao fim visado; } \\
\text { b. em precedentes históricos firmados a propósito de processos seletivos em } \\
\text { universidades públicas [...] este Supremo Tribunal Federal emitiu denso } \\
\text { pronunciamento a respeito da constitucionalidade de ações afirmativas com } \\
\text { recorte racial implementadas mediante reserva de vagas; } \\
\text { c. o sistema de cotas produziria inúmeros resultados positivos, promovendo } \\
\text { uma espécie de compensação pelo tratamento aviltante historicamente } \\
\text { aplicado à população negra no Brasil (ideia de reparação), viabilizando acesso } \\
\text { preferencial a uma plataforma importante para subsidiar o rearranjo das } \\
\text { condições de funcionamento do processo social (ideia de redistribuição), } \\
\text { atenuando, por meio do exemplo positivo, o sentimento de inferiorização } \\
\text { causado pela rarefeita presença de pessoas negras em posições sociais de } \\
\text { prestígio (ideia de reconhecimento) e qualificando o ambiente universitário } \\
\text { pela incorporação de corpo discente com experiências de vida plurais (ideia } \\
\text { de diversidade); } \\
\text { as mesmas premissas então consideradas são também coerentes para justificar } \\
\text { a utilização do recorte racial para a reserva de vagas em postos da } \\
\text { Administração Pública. }\end{array}$ \\
\hline $\begin{array}{l}\text { Argumentos } \\
\text { Teleológicos }\end{array}$ & Não foi possível identificar argumentos dessa categoria. \\
\hline $\begin{array}{l}\text { Argumentos } \\
\text { Deontológicos }\end{array}$ & $\begin{array}{l}\text { a. Na medida em que a ocupação de um cargo público constitui uma ponte para } \\
\text { diversas outras chances de qualificação pessoal, faz todo sentido utilizar a }\end{array}$ \\
\hline
\end{tabular}


reserva de vagas nos concursos públicos como instrumento de promoção da igualdade material.

Fonte: Elaborado pelos autores.

Quadro 3 - Argumentos de Interpretação identificados no voto do Ministro Edson Fachin

\begin{tabular}{|c|c|}
\hline Páginas do Acórdão & 89 a 106 \\
\hline $\begin{array}{l}\text { Argumentos } \\
\text { Linguísticos }\end{array}$ & Não foi possível identificar argumentos dessa categoria. \\
\hline $\begin{array}{l}\text { Argumentos } \\
\text { Sistêmicos }\end{array}$ & $\begin{array}{l}\text { a. É preciso registrar que este Tribunal, quando do julgamento da ADPF 186, } \\
\text { Rel. Ministro Ricardo Lewandowski, Pleno, DJe 17.10.2014, já assentou a } \\
\text { plena constitucionalidade de tais políticas públicas; } \\
\text { b. o precedente é de todo aplicável à hipótese dos autos e a lei objeto desta ação } \\
\text { declaratória atende aos requisitos indicados na ADPF 186: a lei é temporária, } \\
\text { promove a igualdade material, sendo constitucional o fator de distinção, não } \\
\text { há ofensa ao princípio do concurso público e a medida observa o princípio da } \\
\text { proporcionalidade em todas as suas dimensões; } \\
\text { c. medidas como a que consta da lei objeto desta ação declaratória também } \\
\text { encontram fundamento na promoção de igualdade material, como fez } \\
\text { observar o Ministro Ricardo Lewandowski no voto proferido na ADPF 186; } \\
\text { d. o qual, em síntese, acolhe os fundamentos do precedente firmado na ADPF } \\
\text { 186, o sistema de cotas dá pleno cumprimento ao princípio da igualdade } \\
\text { material, um dos pilares do art. } 3^{\circ} \text { da Constituição Federal; } \\
\text { e. a discriminação, nos termos do Artigo I da Convenção para Eliminação da } \\
\text { Discriminação Racial, deriva do uso da "raça" como um instrumento de } \\
\text { regulação social. }\end{array}$ \\
\hline $\begin{array}{l}\text { Argumentos } \\
\text { Teleológicos }\end{array}$ & $\begin{array}{l}\text { a. A legitimidade da desequiparação promovida pela lei está assente, como já } \\
\text { registrou o Relator, na necessidade de superar o racismo institucional e } \\
\text { estrutural. }\end{array}$ \\
\hline $\begin{array}{l}\text { Argumentos } \\
\text { Deontológicos }\end{array}$ & tificar argumentos dessa categoria. \\
\hline
\end{tabular}

Fonte: Elaborado pelos autores.

Quadro 4 - Argumentos de Interpretação identificados no voto da Ministra Rosa Weber Páginas do Acórdão 107 a 116

Argumentos Linguísticos

a. O princípio da eficiência diz com o dever de todo o servidor e da Administração Pública em geral de bem prestar o serviço público, plexo de competências e qualidades desejáveis e esperadas não somente pelo Estado.

a. E alinhada ao quanto por mim decidido no julgamento da ADPF 186, arguição em que esta Corte examinou o sistema de reserva de vagas, igualmente fundado no critério étnico racial, para o ingresso na Universidade de Brasília - UnB, reputo constitucional o diploma normativo pelo qual instituído o sistema de cotas no serviço público federal;

Argumentos Sistêmicos b. Ora, não vislumbro, assim, no bojo da Lei no $12.990 / 2014$, desequiparação a afrontar materialmente o art. $5^{\circ}$, caput, da Carta Política. Ao contrário, identifico na legislação ora submetida a controle a adoção necessária de fator de discrímen legal, exatamente com o objetivo de minorar reconhecida situação de desigualdade.

Não foi possível identificar argumentos dessa categoria.

\begin{tabular}{c|c}
\hline $\begin{array}{c}\text { Argumentos } \\
\text { Teleológicos }\end{array}$ & Não foi possível identificar argumentos dessa categoria. \\
\hline $\begin{array}{c}\text { Argumentos } \\
\text { Deontológicos }\end{array}$ & Não foi possível identificar argumentos dessa categoria. \\
\hline
\end{tabular}

Fonte: Elaborado pelos autores.

Quadro 5 - Argumentos de Interpretação identificados no voto do Ministro Luís Fux

\begin{tabular}{c|rl}
\hline Páginas do Acórdão & & 117 a 122 \\
\hline $\begin{array}{l}\text { Argumentos } \\
\text { Linguísticos }\end{array}$ & a. & $\begin{array}{l}\text { E essa igualdade, como aqui já foi destacado, precisa ser analisada sob dupla } \\
\text { face: quer dizer, a igualdade formal - e as palavras da Lei não conseguem } \\
\text { transformar a realidade -, e a igualdade material, essa que é importante, que }\end{array}$ \\
\hline
\end{tabular}


o Professor Alex [sic.] e o Professor Dvorkin [sic.] ressaltam que é a isonomia ou a igualdade que permitem a desigualação na medida em que há determinados aspectos que tornam as pessoas efetivamente desiguais.

a. O preâmbulo da Constituição integra, de certo, a ordem das normas consideradas as regras e os princípios constitucionais. E aqui está o fundamento de toda essa demanda, porque a desigualação [sic.] é necessária na medida em que o Brasil precisa efetivamente promover o necessário resgate histórico.

\begin{tabular}{cc}
\hline $\begin{array}{c}\text { Argumentos } \\
\text { Teleológicos }\end{array}$ & Não foi possível identificar argumentos dessa categoria. \\
\hline $\begin{array}{c}\text { Argumentos } \\
\text { Deontológicos }\end{array}$ & Não foi possível identificar argumentos dessa categoria. \\
\hline
\end{tabular}

Fonte: Elaborado pelos autores.

Quadro 6 - Argumentos de Interpretação identificados no voto do Ministro Dias Toffoli Páginas do Acórdão Argumentos 126 a 130

Linguísticos

a. A realização da igualdade impõe, em determinados casos, a submissão dos sujeitos desiguais a tratamentos jurídicos diversos.

a. Formulado na ADPF $n^{\circ} 186$ [...] na compatibilidade da política de cotas nas universidades com o princípio da igualdade e com o postulado do Estado Democrático de Direito. Em meu entender, a mesma compreensão se aplica ao presente caso, em que se tem, também, uma política destinada a reduzir as desigualdades fáticas entre brancos e negros;

b. a medida em questionamento não é apenas compatível com a Constituição Federal, sendo uma exigência do princípio da isonomia, previsto pelo art. $5^{\circ}$, caput, da Constituição Federal;

c. a adequada identificação do conteúdo assumido pelo princípio da isonomia na sistemática constitucional vigente depende de sua devida contextualização, à vista, especialmente, do postulado do Estado Democrático de Direito, contemplado no art. $1^{\circ}$, caput, da Constituição da República;

Argumentos Sistêmicos

d. o postulado do Estado Democrático do Direito, adotado pela Constituição de 1988, compatibiliza-se tão somente com um conceito inclusivo de igualdade, ou seja, com a "igualdade aritmética", que confere a todas as pessoas idêntica importância;

e. este Supremo Tribunal Federal já reconheceu a constitucionalidade da instituição de reserva de vaga em concurso público para candidato portador de deficiência física;

f. outrossim, esta Corte reconhece a constitucionalidade do sistema de cotas para negros em universidades, conforme assentado na já mencionada ADPF $\mathrm{n}^{\circ} 186$ (Rel. Min. Ricardo Lewandowski, Tribunal Pleno, DJe de 20/10/14) e no RE com Repercussão Geral no 597.285.

\begin{tabular}{c|c}
\hline $\begin{array}{c}\text { Argumentos } \\
\text { Teleológicos }\end{array}$ & Não foi possível identificar argumentos dessa categoria. \\
\hline Argumentos & Não foi possível identificar argumentos dessa categoria. \\
\hline
\end{tabular}

Fonte: Elaborado pelos autores.

Quadro 7 - Argumentos de Interpretação identificados no voto do Ministro Ricardo Lewandowski

\begin{tabular}{c|c}
\hline Páginas do Acórdão & \multicolumn{1}{c}{132 a 137 } \\
\hline $\begin{array}{c}\text { Argumentos } \\
\text { Linguísticos }\end{array}$ & Não foi possível identificar argumentos dessa categoria. \\
\hline $\begin{array}{c}\text { Argumentos } \\
\text { Sistêmicos }\end{array}$ & $\begin{array}{l}\text { O tema da constitucionalidade das ações afirmativas já foi enfrentado com } \\
\text { bastante verticalidade por esta Suprema Corte por ocasião da ADPF 186/DF, } \\
\text { de minha relatoria. Após a realização de audiência pública e intensos debates, } \\
\text { o Plenário desta Corte julgou improcedente a mencionada arguição para } \\
\text { considerá-los compatíveis com a Carta Magna; }\end{array}$ \\
\hline
\end{tabular}




\begin{tabular}{c|c}
\hline & b. $\begin{array}{l}\text { anote-se, nesse sentido, que, assim como nas cotas para universidades, as } \\
\text { cotas para cargos e empregos públicos não violam o princípio da igualdade, } \\
\text { do acesso mediante concurso público ou da eficiência; } \\
\text { registro que editei enquanto estava na Presidência do CNJ a Resolução } \\
203 / 2015 \text { para garantir a reserva de vagas aos negros no âmbito do Poder } \\
\text { Judiciário. }\end{array}$ \\
\hline $\begin{array}{c}\text { Argumentos } \\
\text { Teleológicos }\end{array}$ & Não foi possível identificar argumentos dessa categoria. \\
\hline $\begin{array}{c}\text { Argumentos } \\
\text { Deontológicos }\end{array}$ & Não foi possível identificar argumentos dessa categoria. \\
\hline
\end{tabular}

Fonte: Elaborado pelos autores.

Quadro 8 - Argumentos de Interpretação identificados no voto do Ministro Celso de Mello Páginas do Acórdão

a. A Convenção Internacional sobre a Eliminação de Todas as Formas de Discriminação Racial define-a como "qualquer distinção, exclusão restrição ou preferência baseadas em raça, cor, descendência ou origem nacional ou étnica que tem por objetivo ou efeito anular ou restringir o reconhecimento, gozo ou exercício num mesmo plano (em igualdade de condição), de direitos humanos e liberdades fundamentais no domínio político econômico, social, cultural ou em qualquer outro domínio de vida pública";

b. o Estatuto da Igualdade Racial (Lei $n^{\circ} 12.288 / 2010$ ), por sua vez, considera discriminação racial ou étnico-racial "toda distinção, exclusão, restrição ou preferência baseada em raça, cor, descendência ou origem nacional ou étnica que tenha por objeto anular ou restringir o reconhecimento, gozo ou exercício, em igualdade de condições, de direitos humanos e liberdades fundamentais nos campos político, econômico, social, cultural ou em qualquer outro campo da vida pública ou privada";

Argumentos Linguísticos

c. a igualdade na lei - que opera numa fase de generalidade puramente abstrata - constitui exigência destinada ao legislador, que, no processo de elaboração legislativa, não poderá incluir no projeto respectivo fatores de discriminação responsáveis pela ruptura da ordem isonômica. A igualdade perante a lei, contudo, pressupondo lei já elaborada, traduz imposição destinada aos demais poderes estatais que, na aplicação concreta da norma legal, não poderão subordiná-la a critérios que ensejem tratamento seletivo ou discriminatório;

d. os magistrados e Tribunais, no exercício de sua atividade interpretativa, especialmente no âmbito dos tratados internacionais de direitos humanos, devem observar um princípio hermenêutico básico (tal como aquele proclamado no Artigo 29 da Convenção Americana sobre Direitos Humanos) consistente em atribuir primazia à norma que se revele mais favorável à pessoa humana, em ordem a dispensar-lhe a mais ampla proteção jurídica.

a. A discriminação racial, que traduz gesto inaceitável de perversão moral, tem encontrado mecanismos destinados a combatê-la, seja mediante instrumentos de repressão penal (CF, art. $5^{\circ}$, XLII, c/c a Lei no 7.716/89);

b. ordenamento positivo brasileiro, na linha do que estabelece o Estatuto da Igualdade Racial (Lei $\mathrm{n}^{\circ}$ 12.288/2010), adota como diretriz político-jurídica a inclusão das vítimas de desigualdade étnico-racial, a valorização da igualdade étnica e o fortalecimento da identidade nacional brasileira; sem se considerar que a Constituição impõe ao Estado o dever de atribuir aos desprivilegiados - verdadeiros marginais do sistema jurídico nacional - a condição essencial de titulares do direito de serem reconhecidos como pessoas investidas de dignidade e merecedoras do respeito social, não se tornará possível construir a igualdade nem realizar a edificação de uma sociedade justa, fraterna e solidária, frustrando-se, assim, um dos objetivos fundamentais da República (CF, art. $\left.3^{\circ}, \mathrm{I}\right)$;

Argumentos Sistêmicos

c. a prática do racismo e da discriminação configura grave violação de todos os direitos humanos e representa ilícito obstáculo ao gozo pleno e integral de tais direitos e prerrogativas, significando, em sua concreta expressão, injusta denegação do dogma de que todos os seres humanos, sem qualquer distinção, nascem livres e iguais em dignidade e em direitos; 
d. a importante Conferência Internacional de Durban, em 2001, na África do Sul, reconheceu que o racismo e a discriminação étnico-racial constituem a própria negação dos princípios, dos propósitos e dos objetivos proclamados tanto pela Carta de São Francisco, que instituiu, em setembro de 1945, a Organização das Nações Unidas, quanto pela Declaração Universal dos Direitos da Pessoa Humana, promulgada em 10/12/1948;

e. que se dê consequência (e consequência efetiva) aos compromissos que o Brasil assumiu tanto no plano doméstico - proclamando, no texto de nossa Constituição, [...] quanto perante a comunidade internacional, [...] a Convenção Internacional sobre a Eliminação de Todas as Formas de Discriminação Racial (1966) e a Declaração Universal dos Direitos da Pessoa Humana (1948), de um lado, e os Pactos Internacionais de 1966, quer sobre os direitos civis e políticos, quer sobre os direitos econômicos, sociais e culturais, de outro, além da Declaração e do Programa de Ação de Viena, adotados na Conferência Mundial sobre Direitos Humanos, que se realizou, na década de 90, na capital austríaca;

f. busca-se, enfim, por esses meios, compensar situações de desnível que historicamente se registraram e que ainda, lamentavelmente, subsistem no Brasil;

g. impende enfatizar que, em razão da Conferência de Durban, os Estados nacionais foram instados a adotar programas de ações afirmativas ou medidas de ações positivas, em ordem a viabilizar o acesso aos serviços públicos e aos serviços sociais básicos em favor dos indivíduos que são vítimas de exclusão ou de discriminação;

h. a Convenção Internacional sobre a Eliminação de Todas as Formas de Discriminação Racial, já incorporada, formalmente, ao plano do Direito Positivo interno brasileiro, estimula, em suas diversas cláusulas, a adoção da chamada "discriminação positiva ou reversa" [...] advertindo, ainda, que tais medidas não serão consideradas práticas de discriminação racial;

i. no precedente que esta Corte estabeleceu no julgamento da ADPF 186/DF, destacou, precisamente, esse aspecto que venho de mencionar: as medidas compensatórias somente deverão ser implementadas enquanto subsistirem as situações de injusta exclusão que elas objetivam neutralizar;

j. fragmento da decisão na qual a eminente Ministra CÁRMEN LÚCIA, julgando o RE 676.335/MG, de que foi Relatora, reconheceu a legitimidade constitucional da adoção, pelo legislador comum, da reserva de vagas, assinalando que essa providência revela-se juridicamente válida no contexto de políticas governamentais de ações afirmativas.

a. Tratamento diferenciado a ser conferido à pessoa negra, longe de vulnerar o princípio da isonomia, tem por precípua finalidade recompor o próprio sentido de igualdade que anima as instituições republicanas.

\begin{tabular}{|c|c|}
\hline $\begin{array}{l}\text { Argumentos } \\
\text { Teleológicos }\end{array}$ & $\begin{array}{l}\text { a. Tratamento diferenciado a ser conferido à pessoa negra, longe de vulnerar o } \\
\text { princípio da isonomia, tem por precípua finalidade recompor o próprio } \\
\text { sentido de igualdade que anima as instituições republicanas. }\end{array}$ \\
\hline $\begin{array}{l}\text { Argumentos } \\
\text { Deontológicos }\end{array}$ & ategoria. \\
\hline
\end{tabular}

Fonte: Elaborado pelos autores.

Quadro 9 - Argumentos de Interpretação identificados no voto da Ministra Cármen Lúcia Páginas do Acórdão 163 a 184

a. Ao regular o art. 37, inc. VIII, da Constituição da República, no art. $5^{\circ}, \S 2^{\circ}$, da Lei n. 8.112/1990, assegurou-se aos portadores de necessidades especiais o direito de se inscreverem em concursos públicos para o provimento de cargos cujas atribuições sejam compatíveis com sua deficiência, reservando a eles até $20 \%$ (vinte por cento) das vagas; Argumentos
Linguísticos b. no art. 37, inc. II, da Constituição da República se condiciona a investidura em cargo ou emprego público à "aprovação prévia em concurso público de provas ou de provas e títulos, de acordo com a natureza e a complexidade do cargo ou emprego (...)".

c. no inc. I desse dispositivo legal, assegura-se o acesso aos cargos, empregos e funções públicas a todos os brasileiros que preencham os requisitos estabelecidos em lei, "assim como aos estrangeiros, na forma da lei". 


\begin{tabular}{|c|c|c|}
\hline $\begin{array}{l}\text { Argumentos } \\
\text { Sistêmicos }\end{array}$ & $\begin{array}{l}\mathrm{j} . \\
\mathrm{k} .\end{array}$ & 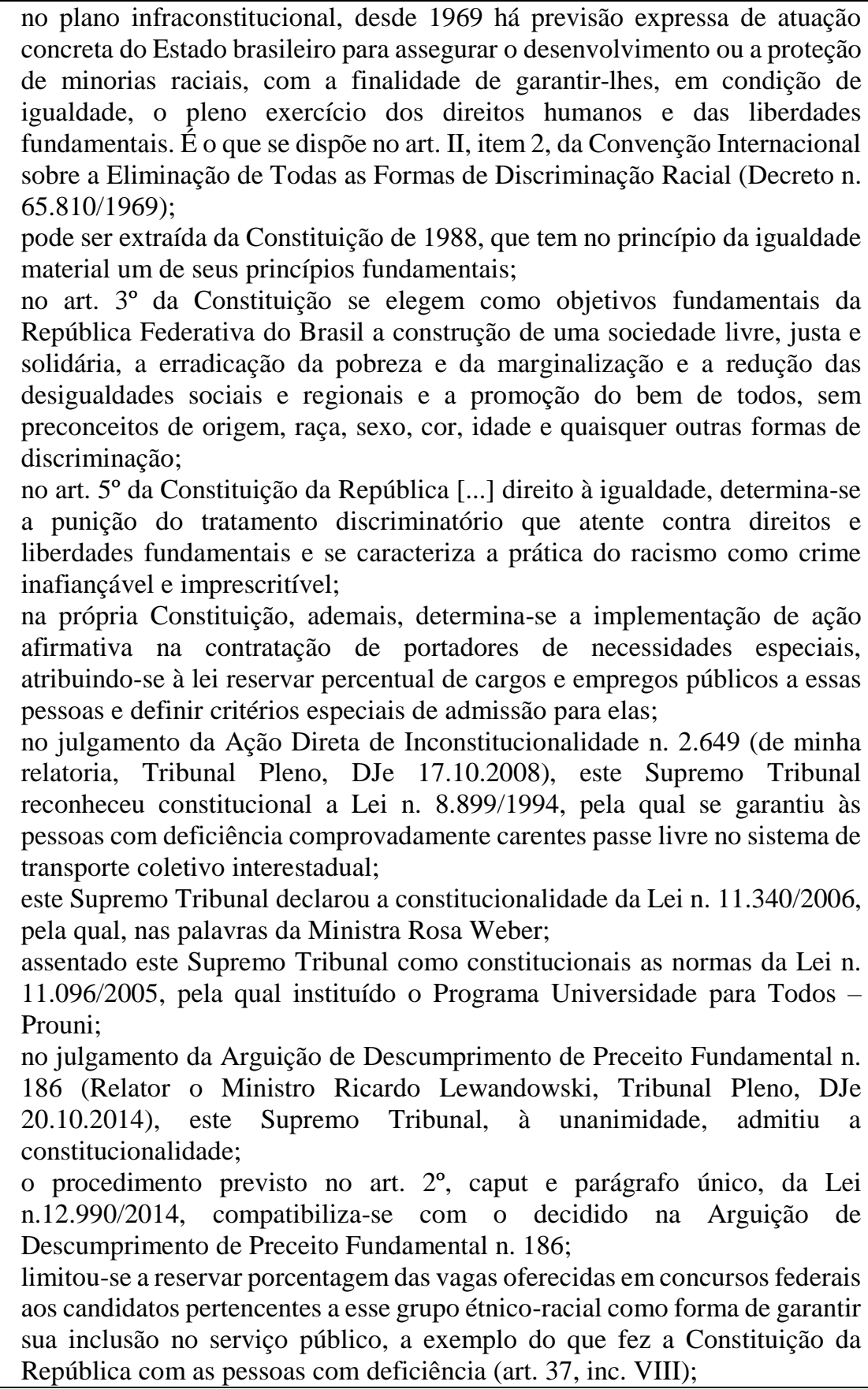 \\
\hline $\begin{array}{l}\text { Argumentos } \\
\text { Teleológicos }\end{array}$ & & $\begin{array}{l}\text { Afigura-se, pois, proporcional e razoável, se levado em conta a reduzida } \\
\text { participação dessas pessoas no serviço público federal, em especial em } \\
\text { carreiras que oferecem remuneração mais elevada. }\end{array}$ \\
\hline $\begin{array}{l}\text { Argumentos } \\
\text { Deontológicos }\end{array}$ & & argumentos dessa categoria. \\
\hline
\end{tabular}

Fonte: Elaborado pelos autores.

Dessarte, convém avaliar os argumentos interpretativos a partir dos requisitos de universalidade, consistência, coerência e consequência propostos por Neil MacCormick. Com o intuito de verificar se, no que tange ao direito à igualdade, os ministros decidiram de forma racional ou discricionária. 


\section{AVALIAÇÃO DO ACORDÃO CONFORME OS REQUISITOS DE UNIVERSALIDADE, CONSISTÊNCIA, COERÊNCIA E CONSEQUÊNCIA PROPOSTOS POR NEIL MACCORMICK}

A teoria de Neil MacCormick ${ }^{29}$ estabelece a argumentação jurídica como uma ramificação da argumentação prática. Nessa última, podem ser apresentados fundamentos que podem ser razões contra ou a favor de fazer algo ou motivos para sustentar uma opinião sobre o que se deve ou se pode fazer.

Ao passo que, na argumentação jurídica, os argumentos devem ser utilizados para mostrar razões em favor da interpretação preferida ${ }^{30}$, em um cenário em que o julgamento interpretativo é condição necessária de aplicabilidade da norma para tomar a decisão, de modo que se utiliza do método silogístico.

Dessa forma, em situações de fato, a consequência é a pura aplicação da norma por meio da subsunção, em conjunto com a utilização de critérios de interpretação. Assim, Manuel Atienza ${ }^{31}$ estabelece que essa justificação é do tipo dedutiva, haja vista que segue o raciocínio jurídico lógico.

Mas, para que seja aplicado é preciso que se atenda a determinados pressupostos. Nesse sentido, a regra do Direito a ser empregada deve ser válida, o juiz a deve identificar como tal, implicando na exigência de critérios de reconhecimento do dispositivo normativo. ${ }^{32}$

Contudo, em alguns casos, essa alegação dedutiva não é suficiente, o intérprete se encontrará em uma situação em que a escolha não será simples. De forma que, para Manuel Atienza $^{33}$ a concepção de enunciados normativos ou fáticos podem gerar dilemas.

Desse modo, a formulação de premissas normativas pode suscitar problemas de interpretação. Em que não há dúvida acerca da aplicação da norma, contudo não se sabe qual interpretação deve ser aplicada. Bem como, de pertinência, na qual inexiste norma aplicável ao caso. $^{34}$

Ao passo que, conforme Manuel Atienza ${ }^{35}$, argumentos fáticos suscitam questões de prova, em que, o conjunto probatório do presente é verdadeiro e a partir disso, faz-se inferências sobre o passado. E também questões de qualificação, de forma que não há dúvida sobre a existência de determinados fatos, a discussão está na integração ou não da norma ao caso.

Assim, tais problemas ocorrem em casos considerados difíceis, em que a simples subsunção não é possível. Sendo necessário, para tanto, uma justificação de segunda ordem. Ou critérios avaliativos, que "servem para refletir sobre a racionalidade argumentativa da resposta

\footnotetext{
${ }^{29}$ MACCORMICK, Neil. Argumentación e interpretación en el Derecho. Doxa, Cuadernos de Filosofía del Derecho, v. 33, p. 55-78, 2010.

${ }^{30}$ MACCORMICK, Neil. Argumentación e interpretación en el Derecho. Doxa, Cuadernos de Filosofía del Derecho, v. 33, p. 55-78, 2010.

31 ATIENZA, Manuel. As razões do direito: teoria da argumentação jurídica. 2. ed. Rio de Janeiro: Forense Universitária, 2014.

${ }^{32}$ RUBINGER-BETTI, Gabriel; ROESLER, Claudia. As limitações e possibilidades dos critérios avaliativos propostos por Neil MacCormick para a argumentação jurídica. Revista de Direitos e Garantias Fundamentais, v. 18, n. 1, p. 133-164, 2017.

33 ATIENZA, Manuel. As razões do direito: teoria da argumentação jurídica. 2. ed. Rio de Janeiro: Forense Universitária, 2014.

${ }^{34}$ RUBINGER-BETTI, Gabriel; ROESLER, Claudia. As limitações e possibilidades dos critérios avaliativos propostos por Neil MacCormick para a argumentação jurídica. Revista de Direitos e Garantias Fundamentais, v. 18, n. 1, p. 133-164, 2017.

35 ATIENZA, Manuel. As razões do direito: teoria da argumentação jurídica. 2. ed. Rio de Janeiro: Forense Universitária, 2014.
}

Revista de Direito Brasileira | Florianólopis, SC | v. 25 | n. 10 | p. 35-55 | Jan./Abr. 2020 
construída como solução do problema jurídico em um caso concreto, quando sua justificação é analisada a posteriori"’ 36

Desse modo, para Argemiro Cardoso Martins, Cláudia Rosane Roesler e Ricardo Antonio Rezende de Jesus ${ }^{37}$, a ideia de Neil MacCormick é oferecer um teste de adequação, no qual se verifica se a decisão judicial preenche os requisitos de universalidade, coerência, consistência e consequência.

O primeiro ponto é a universalidade, que pode ser entendida a partir da concepção de que a decisão deve conter uma premissa geral, que possa ser reproduzida, no caso de idêntica situação, em outro momento. ${ }^{38}$

Manuel Atienza ${ }^{39}$ explica que o alcance desse critério deve se estender sobre o passado e o futuro. De modo que, o caso presente deve ser decidido de acordo com os critérios utilizados no passado, ao mesmo tempo em que, pode servir de parâmetro para decisões posteriores. Assim, a universalidade está ligada ao sistema de precedentes. ${ }^{40}$ Nesse sentido, da decisão deve originar uma norma geral que possa ser reproduzida em outros casos com as mesmas características.

O segundo e o terceiro requisitos estão relacionados com a justificação acerca da escolha de determinada norma, nessa conformidade a decisão deve ter sentido tanto em relação a si mesma quanto ao ordenamento jurídico que se trate. Conforme Manuel Atienza ${ }^{41}$, o argumento de consistência apresenta fragilidades e, para tanto, faz-se preciso a verificação da coerência. Contudo, não significa que aquela seja requisito dessa.

Nesse sentido, a consistência é um requisito que tem como objetivo auferir se a decisão está em conformidade com as normas jurídicas válidas. ${ }^{42}$ Desse modo, busca verificar se há contradição lógica entre as proposições da própria decisão.

Ao passo que, a coerência, inicialmente, apresenta a distinção acerca de sua modalidade normativa e narrativa. De acordo com Argemiro Cardoso Martins, Cláudia Rosane Roesler e Ricardo Antonio Rezende de Jesus 43 "é preciso que, ao fundamentar uma decisão, os fatos narrados façam parte de uma sequência inteligível de eventos que façam sentido como um todo". Assim, ao avaliar a decisão judicial, deve-se observar se o agente jurisdicional apresentou os fatos de modo que a fundamentação ocorra a partir da lógica narrativa. Caso não haja lógica ou apresentação de fatos, a decisão é incoerente no que tange a modalidade narrativa.

Enquanto que, a coerência normativa é a observância se a decisão está em harmonia com o princípio geral escolhido para justificar a sentença, e se esse está em conformidade com o

\footnotetext{
${ }^{36}$ RUBINGER-BETTI, Gabriel; ROESLER, Claudia. As limitações e possibilidades dos critérios avaliativos propostos por Neil MacCormick para a argumentação jurídica. Revista de Direitos e Garantias Fundamentais, v. 18, n. 1, p. 133-164, 2017, p. 139.

${ }^{37}$ MARTINS, Argemiro Cardoso Moreira; ROESLER, Cláudia Rosane; DE JESUS, Ricardo Antonio Rezende. A noção de coerência na teoria da argumentação juridica de Neil MacCormick: caracterização, limitações, possibilidades. Novos Estudos Jurídicos, v. 16, n. 2, p. 207-221, 2011.

${ }^{38}$ MARTINS, Argemiro Cardoso Moreira; ROESLER, Cláudia Rosane; DE JESUS, Ricardo Antonio Rezende. A noção de coerência na teoria da argumentação juridica de Neil MacCormick: caracterização, limitações, possibilidades. Novos Estudos Jurídicos, v. 16, n. 2, p. 207-221, 2011.

${ }_{39}$ ATIENZA, Manuel. As razões do direito: teoria da argumentação jurídica. 2. ed. Rio de Janeiro: Forense Universitária, 2014.

${ }^{40}$ RUBINGER-BETTI, Gabriel; ROESLER, Claudia. As limitações e possibilidades dos critérios avaliativos propostos por Neil MacCormick para a argumentação jurídica. Revista de Direitos e Garantias Fundamentais, v. 18, n. 1, p. 133-164, 2017.

${ }^{41}$ ATIENZA, Manuel. As razões do direito: teoria da argumentação jurídica. 2. ed. Rio de Janeiro: Forense Universitária, 2014.

${ }^{42}$ RUBINGER-BETTI, Gabriel; ROESLER, Claudia. As limitações e possibilidades dos critérios avaliativos propostos por Neil MacCormick para a argumentação jurídica. Revista de Direitos e Garantias Fundamentais, v. 18, n. 1, p. 133-164, 2017.

${ }^{43}$ MARTINS, Argemiro Cardoso Moreira; ROESLER, Cláudia Rosane; DE JESUS, Ricardo Antonio Rezende. A noção de coerência na teoria da argumentação juridica de Neil MacCormick: caracterização, limitações, possibilidades. Novos Estudos Jurídicos, v. 16, n. 2, p. 207-221, 2011, p. 251.
}

Revista de Direito Brasileira | Florianólopis, SC | v. 25 | n. 10 | p. 35-55 | Jan./Abr. 2020 
ordenamento jurídico, seja no que se refere a princípios como valores. ${ }^{44}$ Assim, para Gabriel Rubinger-Betti e Caláudia Roesler, a argumentação por meio da coerência envolve dois fatores, "a investigação de princípios e valores que dão sentido às normas jurídicas semelhantes ao caso", e "a aplicação dos princípios ao caso em questão". ${ }^{45}$

Desse modo, esse requisito se refere a obrigatoriedade em que todas as proposições da decisão estejam congruentes na sua totalidade, assim como, em relação ao sistema jurídico no qual fazem parte, no que se refere aos princípios jurídicos.

Por fim, o argumento consequencialista em que é preciso verificar os impactos da decisão no mundo. Assim, é preciso avaliar as decorrências jurídicas, a partir da decisão, que são estudadas com relação a uma série de valores, como justiça, bem comum, dignidade humana.

Desse modo, a concepção consequencialista de Neil MacCormick é compatível com a utilização de dois tipos de razões substantivas, uma finalista, que busca promover determinado estado de coisas considerado desejável; e outra de correção, que é considerada boa ou correta em si mesma. ${ }^{46}$

Portanto, esse tópico tem como propósito avaliar a ADC n. 41, tanto a ementa da decisão como os votos dos ministros, a partir dos requisitos da universalidade, consistência, coerência e consequência. E, por consequência, identificar se a decisão está correta, a partir dos argumentos de racionalidade propostos por Neil MacCormick.

\subsection{Universalidade}

Do ponto de vista geral, sem considerar o voto de cada ministro especificamente, a decisão cumpre o requisito da universalidade. Haja vista que, o argumento principal é acerca da "constitucionalidade de políticas de ação afirmativa voltadas para o enfrentamento de desigualdades materiais entre brancos e negros, desde que sejam observados os critérios e percentuais razoáveis". 47

Inclusive, tal argumento é uma reprodução de outro julgamento, a Arguição de Descumprimento de Preceito Fundamental n. 186, que o mesmo tribunal proferiu decisão favorável a ação afirmativa de reserva de vagas para negros nos processos seletivos em universidades públicas.

No que se refere ao voto de cada ministro, também foi possível identificar o cumprimento da universalidade. Pois, nenhum voto foi proferido de forma individualizada e generalista, mas sim com possibilidades de aplicações futuras.

\subsection{Consistência}

O requisito de consistência tem como objetivo avaliar se os argumentos elencados estão em consonância, no sentido de apresentarem pontos de fundamentação que seguem a mesma linha de confluência. De forma que, não são argumentos contrários entre si. Esse ponto deve ser

\footnotetext{
44 ATIENZA, Manuel. As razões do direito: teoria da argumentação jurídica. 2. ed. Rio de Janeiro: Forense Universitária, 2014.

${ }^{45}$ RUBINGER-BETTI, Gabriel; ROESLER, Claudia. As limitações e possibilidades dos critérios avaliativos propostos por Neil MacCormick para a argumentação jurídica. Revista de Direitos e Garantias Fundamentais, v. 18, n. 1, p. 133-164, 2017, p. 144.

46 ATIENZA, Manuel. As razões do direito: teoria da argumentação jurídica. 2. ed. Rio de Janeiro: Forense Universitária, 2014.

${ }^{47}$ BRASIL. Supremo Tribunal Federal. Ação Declaratória de Constitucionalidade no 41 . Requerente: Conselho Federal da Ordem dos Advogados do Brasil - CFOAB. Relator: Ministro Luís Roberto Barroso. Brasília, DF, 08 de junho de 2017. Diário Oficial da União: Constitucionalidade da Lei m. 12.990/2014. Brasília, 16 ago. 2017. p. 1-186. Disponível em: <http://portal.stf.jus.br/processos/downloadPeca.asp?id=312447860\&ext=.pdf>. Acesso em: 15 out. 2018 , p. 33.
}

Revista de Direito Brasileira | Florianólopis, SC | v. 25 | n. 10 | p. 35-55 | Jan./Abr. 2020 
analisado no que tange aos votos e as razões proferidas, de modo que elas não apresentem qualquer ambiguidade entre si.

Acerca dos argumentos utilizados pelos ministros, não foi apresentada qualquer contradição lógica, assim, os argumentos utilizados não se contrariam. $\mathrm{O}$ voto do relator, ministro Luís Roberto Barroso, segue um modo de raciocínio lógico dedutivo. Analisando as decisões já proferidas pela corte, no sentido de verificar as semelhanças e decidir, a partir do sistema de precedentes. Depois, passou apreciar a constitucionalidade da decisão, avaliando acerca das diversas dimensões do direito à igualdade, no sentido do racismo estrutural, igualdade como redistribuição e reconhecimento; os princípios do concurso público e da eficiência administrativa; e o princípio da proporcionalidade. Por fim, se debruçando acerca do controle de fraudes, principalmente, por meio da autodeclaração e da heteroidentificação.

Como todos os ministros seguiram o voto do relator, de tal modo que a ação foi decidida por unanimidade, os fundamentos apresentados pelos demais ministros seguiram a mesma lógica, apresentado, assim, consistência.

\subsection{Coerência}

Atender o requisito da coerência significa que os argumentos elencados na decisão estão de acordo com os princípios e demais normas existentes no ordenamento jurídico. Desse modo, pode-se compreender que, no caso analisado em questão, se identifica coerência.

O ponto chave da ADC n. 41 é a constitucionalidade da Lei n. 12.990/2014, contudo, os pontos que geraram controvérsias perante outros juízos, dizem respeito a questão do direito à igualdade, o princípio do concurso público, da eficiência e da proporcionalidade, além da questão referente as fraudes. Nesse sentido, os argumentos proferidos foram no sentido da proteção ao direito à igualdade, principalmente, em relação à sua dimensão material.

Para tanto, os ministros se utilizaram de diversos fundamentos constitucionais, como os presentes nos artigos $3^{\circ}$, I e III, $5^{\circ}$, caput, XLII, que dispõe sobre a igualdade e combate ao racismo. O artigo 37, II e VIII, a exigência de realização de provas e títulos para provimento em cargos da administração pública, além de admitir a adoção de políticas públicas diferenciadoras para pessoas com deficiência.

Assim como razões supralegais, presentes na Convenção Internacional sobre a Eliminação de Todas as Formas de Discriminação Racial, a Conferência Internacional de Durban, a Declaração Universal dos Direitos da Pessoa Humana, Declaração e Programa de Ação de Viena. Por fim, os fundamentos legais, como a Lei n. 7.716, de 5 de janeiro de 1989, que define os crimes resultantes de preconceito de raça e cor, e o Estatuto da Igualdade Racial (Lei n. 12.288/2010). Diante do exposto, pode-se concluir que os votos apresentaram coerência em relação ao ordenamento jurídico brasileiro. Havendo referência com os dispostos constitucionais, à medida que se fazia necessário.

\subsection{Consequência}

O requisito de consequência tem como finalidade aferir se no acórdão foram avaliados os impactos da decisão para o mundo, no sentido de buscar as consequências jurídicas dessa decisão perante a sociedade.

Dessa forma, a ementa da decisão não apresenta qualquer argumento nesse sentido, apenas expõe um resumo do voto do relator, mas sem identificar possíveis consequências jurídicas. Contudo, o ministro Luís Roberto Barroso foi o que mais proferiu posicionamentos favoráveis à decisão, apresentando pontos que viriam a melhorar com a implementação da política de cotas.

O mesmo não pode ser avaliado nos argumentos dos ministros Rosa Weber, Luís Fux,

Dias Toffoli e Ricardo Lewandowski. Esses não apresentaram quaisquer argumentos no sentido de avaliar as consequências de seus votos para a sociedade de modo geral. Dessa forma, compreende- 
se que o acórdão de modo geral, cumpre o requisito de consequência, mas o voto de alguns ministros, em particular, não o satisfaz.

\section{CONCLUSÃO}

Diante do exposto, o presente artigo tinha como objetivo avaliar o teor de racionalidade da ADC n. 41 à luz da teoria de Neil MacCormick. Para tanto, buscou-se apresentar, brevemente, os principais pontos da sua teoria da argumentação jurídica.

Inicialmente, procurou se ater aos argumentos interpretativos, no sentido de compreender as razões linguísticas, sistêmicas, teleológicas e deontológicas. Depois, analisou os votos de cada ministro a partir desses pontos, sistematizando por meio de quadros separativos. Por fim, depreendeu-se acerca dos requisitos de racionalidade da decisão, aferindo se o caso em questão preenchia as condições de universalidade, consistência, coerência e consequência.

Desse modo, pode-se concluir que ao analisar a decisão de forma geral, todas as exigências foram cumpridas. Contudo, o mesmo não se pode afirmar dos votos proferidos por alguns ministros em particular. Haja vista que, os ministros Rosa Weber, Luís Fux e Dias Toffoli não apresentaram argumentos do tipo teleológicos e nem deontológicos, o ministro Edson Fachin não fundamentou de forma linguística e o ministro Ricardo Lewandowski apresentou apenas razões de ordem sistêmica.

Acredita-se que tal questão se deve ao fato de todos os ministros presentes seguirem o voto do relator em sua inteireza. Por isso, não apresentaram votos fundamentados de forma consequencialista. Além disso, alguns pontos merecem destaque, como o fato de o ministro Luís Roberto Barroso ter argumentado sobre a questão do princípio da eficiência e do concurso público, e tal ponto ter sido mencionado apenas nos votos dos ministros Rosa Weber e Ricardo Lewandowski. Sobre a proporcionalidade, apenas a ministra Carmen Lucia se manifestou.

No que se refere à utilização da autodeclaração em conjunto com a heteroidentificação, os ministros Alexandre de Moraes, Edson Fachin, Rosa Weber e Celso de Mello se manifestaram no sentido favorável. Enquanto que acerca da ampliação do âmbito de aplicação do art. $4^{\circ}$ da Lei n. 12.990/2014, para casos de promoção e remoção dos servidores públicos, sendo tal tese acolhida pelos ministros Edson Fachin e Luís Fux, ao passo que, o ministro Dias Toffoli não acolheu a questão, mas sem apresentar argumentos contrários. $\mathrm{O}$ mesmo se dá sobre a possibilidade de estender a disciplina da lei em questão aos Estados e Municípios. Inclusive, tal questão não é apresentada na ementa da decisão.

Esses pontos revelam a ocorrência de um juízo monocrático por parte do pleno do Tribunal, em conjunto com uma insuficiência deliberativa, haja vista a reiteração de votos individuais. Consequências estas que se mostram como reflexo do modelo de decisão seriatim praticado no Tribunal, que se caracteriza pela compilação dos votos e suas ratio decidendi proferidos individualmente pelos membros do órgão colegiado. Dificultando, desse modo, a compreensão acerca da decisão do tribunal e priorizando as decisões individuais de cada Ministro, sendo essas que adquirem o caráter paradigmático no sistema de precedentes. ${ }^{48}$

Portanto, conclui-se que observando os requisitos elencados pela teoria da argumentação jurídica de Neil MacCormick, acerca do teor de racionalidade da decisão, pode-se afirmar que essa cumpre com tais condições. Apesar de que, em alguns momentos, não terem sido tratados pontos que mereciam destaque.

Contudo, demonstrou-se que o teor da ADC n. 41 não se mostrou ativista ou fora do alcance dos preceitos normativos presentes no sistema jurídico brasileiro como um todo. Indicando coerência com o ordenamento e dentro dos demais critérios de racionalidade apresentados por

\footnotetext{
${ }^{48}$ REGINATO, Karla Cristine. Decidir sem deliberar: a integridade no direito como possível solução ao padrão "seriatim" de decisões nos julgamentos do Supremo Tribunal Federal. 2017. 119 f. Dissertação (Mestrado em Direito) - Faculdade IMED, Passo Fundo, 2017.
}

Revista de Direito Brasileira | Florianólopis, SC | v. 25 | n. 10 | p. 35-55 | Jan./Abr. 2020 
MacCormick. Devido ao modelo seriatim de decisão praticado pelo STF, que ao compilar todos os votos proferidos, acaba por abranger todas as dimensões existentes na teoria de MacCormick.

Entretanto, analisando os mesmos votos de forma individual, é possível depreender que a maioria dos ministros não é capaz de elencar argumentos que componham as categorias propostas por MacCormick. Desse modo, cada ratio decidendi individual não poderia ser considerada racional.

A possível irracionalidade das decisões particularizadas dos ministros poderia ser mais facilmente evitada por meio da adoção do modelo de decisão tipo per curiam, já que se privilegiaria a apresentação do resultado da deliberação do tribunal. Podendo, assim, o acórdão ser construído após a deliberação individual, exaurindo todas as causas de pedir da ação, por meio de uma teoria de argumentação racional como a de Neil MacCormick.

\section{REFERÊNCIAS}

ATIENZA, Manuel. As razões do direito: teoria da argumentação jurídica. 2. ed. Rio de Janeiro: Forense Universitária, 2014.

BARROSO, Luís Roberto. Fundamentos teóricos e filosóficos do novo Direito Constitucional brasileiro. Revista de Direito Administrativo, v. 225, p. 5 - 37, jul.set. 2001.

BRASIL. Supremo Tribunal Federal. Ação Declaratória de Constitucionalidade no 41.

Requerente: Conselho Federal da Ordem dos Advogados do Brasil - CFOAB. Relator: Ministro Luís Roberto Barroso. Brasília, DF, 08 de junho de 2017. Diário Oficial da União:

Constitucionalidade da Lei m. 12.990/2014. Brasília, 16 ago. 2017. p. 1-186. Disponível em: $<$ http://portal.stf.jus.br/processos/downloadPeca.asp?id=312447860\&ext=.pdf>. Acesso em: 15 out. 2018.

LIMA, Martonio Mont'Alverne Barreto; MOTA, Rafael Gonçalves. O julgamento do Habeas Corpus 126.292/SP pelo supremo tribunal federal sob a óptica do pensamento de Neil Maccormick sobre argumentação da decisão judicial. Revista Observatório, v. 4, n. 5, p. 750787, 2018.

LOPES, Ana Maria D.; BENÍCIO, Márcio. Análise da decisão judicial sobre a "briga de


Brasileira de Direito Animal, Salvador, v. 10, n. 20, p. 37-58, 2015.

MACCORMICK, Neil. Argumentação jurídica e teoria do direito. 2. ed. São Paulo: WMF Martins Fontes, 2009.

MACCORMICK, Neil. Argumentación e interpretación en el Derecho. Doxa, Cuadernos de Filosofía del Derecho, v. 33, p. 55-78, 2010.

MARTINS, Argemiro Cardoso Moreira; ROESLER, Cláudia Rosane; DE JESUS, Ricardo Antonio Rezende. A noção de coerência na teoria da argumentação juridica de Neil MacCormick: caracterização, limitações, possibilidades. Novos Estudos Jurídicos, v. 16, n. 2, p. 207-221, 2011.

REGINATO, Karla Cristine. Decidir sem deliberar: a integridade no direito como possível solução ao padrão "seriatim" de decisões nos julgamentos do Supremo Tribunal Federal. 2017. 119 f. Dissertação (Mestrado em Direito) - Faculdade IMED, Passo Fundo, 2017. 
RUBINGER-BETTI, Gabriel; ROESLER, Claudia. As limitações e possibilidades dos critérios avaliativos propostos por Neil MacCormick para a argumentação jurídica. Revista de Direitos e Garantias Fundamentais, v. 18, n. 1, p. 133-164, 2017.

STRECK, Lenio Luiz. Entre o ativismo e a judicialização da política: a difícil concretização do direito fundamental a uma decisão judicial constitucionalmente adequada. Espaço Jurídico Journal of Law [EJJL], v. 17, n. 3, p. 721-732, 2016. 